\title{
El-Fayah
}

JURNAL BIOLOGI

Journal Homepage: http://ejournal.uin-malang.ac.id/index.php/bio/index

e-ISSN: 2460-7207, p-ISSN: 2086-0064

Original research article

\section{Insilico Analysis of the Potential Phytoestrogens of Selected Alkaloid from Soursop (Annona muricata) Leaves}

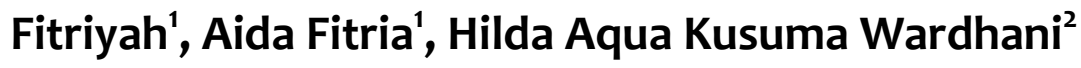

\author{
${ }^{1}$ Biology Study Program, Faculty of Science and Technology, Maulana Malik Ibrahim State \\ Islamic University of Malang, East Java \\ ${ }^{2}$ Educational Biology Study Program, University of Kapuas Sintang, West Kalimantan \\ *Corresponding author \\ Email: fitriyahfaizin@bio.uin-malang.ac.id \\ DOI: 10.18860/elha.v8i2.12314
}

\begin{tabular}{l} 
A r t i c l e I n f o \\
\hline Article history: \\
Received 26 February 2021 \\
Received in revised form \\
01 March 2021 \\
Accepted 15 March 2021 \\
\hline
\end{tabular}

Key Word:

Phytoestrogens

Alkaloid

Annona muricata

In silico

\begin{abstract}
Estrogen is an important hormone in the female reproductive system, as well as other systems in men and women. The decrease of estrogen levels mainly occurs in the menopause phase. The decrease of estrogen is one indication of the presence of various diseases such as cardiovascular disease. Decreased levels of estrogen can be treated by administering exogenous estrogen such as Estradiol-17b. However, long-term administration of estradiol plays an important role in tumor cell growth. Phytoestrogens are plant-based polyphenolic compounds that have a structure and biological activity similar to the estrogen. Phytoestrogens can be derived from alkaloid compounds, one of which is found in the soursop (Annona muricata) leaves. The purpose of this study was to analysis the potential phytoestrogens of selected alkaloid in the A. muricata leaves. The analysis was carried out using the insilico approach using molecular docking methods, pharmacokinetic analysis and druglikeness. The molecular docking results showed that the ligands could bind to the receptors on the specific binding site with the lowest binding affinity value approaching the control ligands, namely the Anonaine compound of $-8.6 \mathrm{kcal} / \mathrm{mol}$, followed by Xylopine compound of $-7.8 \mathrm{kcal} / \mathrm{mol}$ and Annonamine of $-7.0 \mathrm{kcal} / \mathrm{mol}$. The results of pharmacokinetic and druglikeness showed that all ligand compounds have a good ability to be absorbed in the gastrointestine and have a good bioavalaibility as an oral drug.
\end{abstract}




\section{INTRODUCTION}

Estrogen is a hormone that plays an important role in sexual development and reproduction, especially in women. Estrogen is produced in the ovary and has one of the main functions in regulating the estrous or menstrual cycle in women, therefore estrogen is very important for female reproduction. Estrogen is not only important for reproduction, but also in other systems such as the neuroendocrine, skeletal and immune system in men and women (Hamilton et al., 2014). The main mechanism of action of estrogen is through the expression of estrogen receptors (ER) (Couse et al., 1997), both mediated by ERa which is dominant in the liver, uterus, mammary glands, pituitary, hypothalamus, cervix, and vagina, and ER $\beta$ which is dominant in the ovaries, lungs and prostate. (Nilsson et al., 2001).

The decrease of estrogen levels caused by various factors, mainly menopause. Menopause occurs when a woman stops ovulating and her monthly periods (menstruation) stop. The absence of estrogen during the menopausal phase is an indicative of the cardiovascular disease, which is characterized by variations in the lipid profile and predominantly abdominal fat accumulation (Hemalatha et al., 2019). Estradiol (E2) is the one of exogenous estrogen that can be used for hormone therapy in the menopause phase (Fait, 2019). However, long-term administration of exogenous estradiol plays an important role in facilitating tumor development both of by estrogen receptor and non-receptor mechanisms (Yue et al., 2010).

Phytoestrogens are the polyphenolic and non-steroid compounds which have a structure and biological activity similar to estrogen in humans (Nikolić et al., 2017). Most of the phytoestrogens are found in flavonoids and isoflavones. The reports of the potential phytostrogens of alkaloid structure are extremely rare. A possible reason for being neglected in the exploration for estrogenity could be that they are generally considered toxic. However, the striking structural variations of a large number of natural alkaloids are the basis of a broad spectrum of quite diverse activities. In addition, several pharmacological studies have shown that some alkaloids belonging to different chemical subgroups show only low toxicity. Alkaloids had a potential as a source of new phytoesterogens (Djiogue et al., 2014).

Soursop (Annona muricata) is a plant that is widely used as a traditional medicine and contains a number of alkaloids, especially in the leaves. (Abdul Wahab et al., 2018). Based on this background, it is deemed necessary to study the potential of phytoestrogens derived from alkaloids of $A$. muricata leaves.

\section{MATERIALS AND METHODS}

This research based on the insilico method which was conducted from April to June 2019 at the Laboratory of the Biology Study Program, Faculty of Science and Technology UIN Maulana Malik Ibrahim Malang.

\section{a. Samples Preparation}

Alkaloid derivatives of $A$. muricata used as ligan are: annonamine (PubChem CID: 56929881), anonaine (PubChem CID: 160597) and xylopine (PubChem CID: 160503). Estradiol 17- $\beta$ (PubChem CID: 5757 ) used as a ligan control. Test and control ligands are downloaded in 3D format via PubChem Compound

(https://www.ncbi.nlm.nih.gov/pccompound/). Ligand preparation was carried out by minimizing all active compound structures at PyRx 0.8. ERa structure as a reseptor downloaded from Protein Data Bank (RSCB) PDB ID: $1 A 52$ (https://www.rscb.org). The water and drug molecules attached to the protein receptor structure are removed and the hydrogen atoms are eliminated. 
b. Molecular Docking Analysis

Docking analysis was carried out using the Autodock Vina program in Pyrx software (Trott and Arthur, 2010) to find out the interaction between ligand and receptor. The result is binding affinity values in $\mathrm{kcal} / \mathrm{mol}$ which will compared with the binding affinity value of control ligands as a basis for determine which alkaloids from the $A$. murcata leaves have an estrogenic effect with binding values close to the control ligands. Visualization of docking results was carried out using Pymol software, while interaction visualization in 3D using Discovery Studio software.

\section{c. Pharmacokinetics analysis}

Pharmacokinetic analysis was carried out through absorption, distribution, metabolism, and excretion (ADME) analysis of the ligands used in the study. ADME analysis was performed using SwissADME software (https://www.swissadme.ch)

\section{RESULTS}

$R$ The ligands used in the study are annonamine, anonaine and xylopine which are the alkaloid compounds in A. muricata leaves (Abdul Wahab et al., 2018). The receptor used was an Estrogen Receptor alpha (ERa) (Figure 1). Estradiol-17 $\beta$ was used as a comparison ligand (control ligand). The ligand structure used in the study was shown in Figure 2.

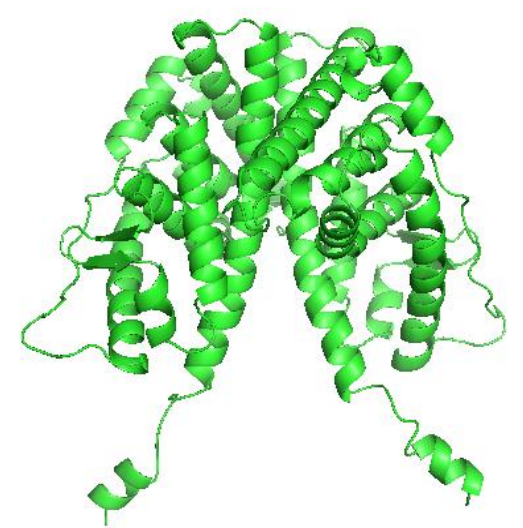

Figure 1. 3D strukcture of Estrogen Receptor Alpha (ERa)

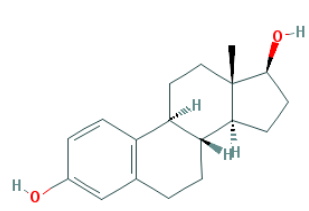

a

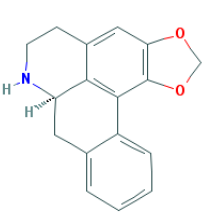

C

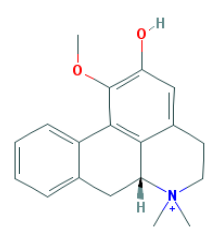

b

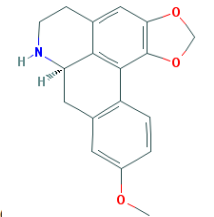

d

Figure 2. The ligands (a) Estradiol-17 $\beta$, (b) Annonaine, (c) Anonaine, (d) Xylopine.

The results of molecular docking showed the presence of an alkaloid compound that is suitable for binding with ERa. The results showed that the anonaine compound had the smallest binding affinity value compared to other compounds (Figure 3). The smaller the binding energy, the better the stability of the bond between the ligand and the receptor because the bonds formed are stronger.

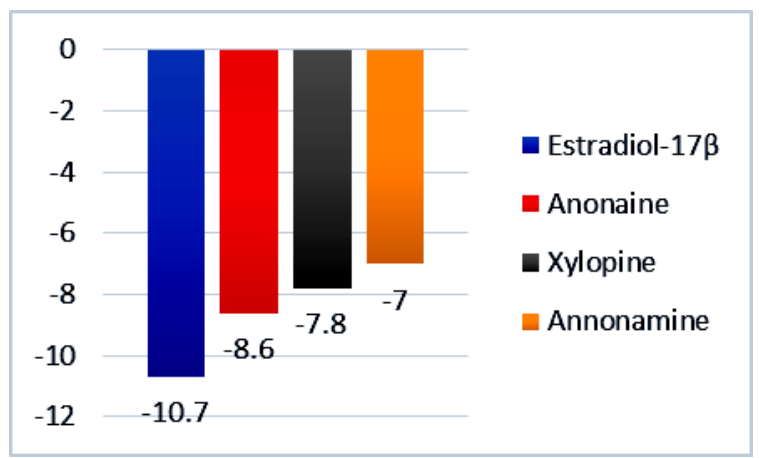

Figure 3. Binding affinity values of alkaloid compound of $A$. muricata leaves with $E R a$

The results of the molecular docking were visualized using discovery studio software to found the binding of amino acid residues and then analyzed whether the ligand with the lowest energy also had the same bonded amino acids residue with the control ligand. This is important to know so we can predict the key of amino acids used to interact. The 
results of visualization using discovery studio software showed that the selected alkaloid compounds of A. muricata leaves had some of the same binding residues as the control ligand (Estradiol-17ß). Among the same binding residues indicated the type of alkyl bond at the Leu 220, Leu 86 and Ala 45 residues for Annonamine; lle 119, Leu 79 and Ala 45 for Anonamine; LEu 220, Leu 79 and Ala 45 for Xylopine (Figure 4)

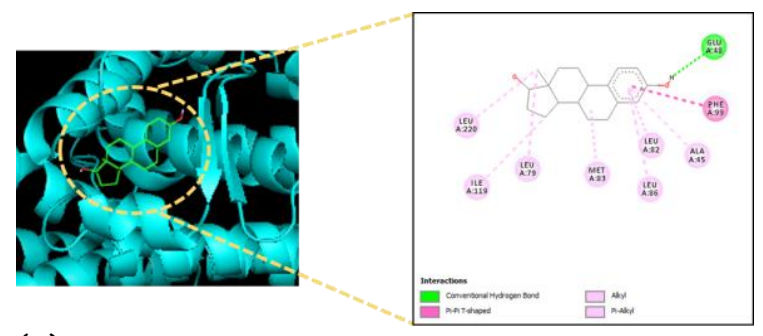

(a)

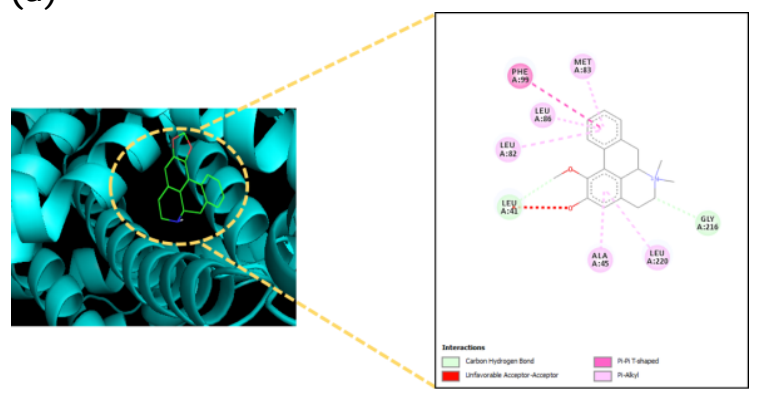

(b)

Figure 4. Molecular interaction analysis docking (a) Estradiol-17 $\beta$ (b) Anonamine

The results of pharmacokinetic analysis showed that the selected alkaloid compounds from $A$. muricata leaves had a good ability to be absorbed in the gastrointestinal tract indicated by the "High" category in the $\mathrm{Gl}$ Absorption parameter. Meanwhile, the druglikeness results showed that the selected alkaloid compounds could be used as oral drugs (Table 1). The bioaviability score of 0.55 indicates that the active compound has a bioaviability potential of $>10 \%$ (Zhu et al., 2011).
Tabel 1. Analysis result of swissADME

\begin{tabular}{|c|c|c|c|c|}
\hline \multirow[b]{2}{*}{$\begin{array}{c}\text { Active } \\
\text { Compound }\end{array}$} & \multicolumn{2}{|c|}{ Pharmakokinetik } & \multicolumn{2}{|c|}{ Druglikeness } \\
\hline & $\begin{array}{c}\text { GI } \\
\text { Absorbtion }\end{array}$ & $\begin{array}{c}\log \\
\mathrm{Kp} \\
(\mathrm{cm} / \mathrm{s})\end{array}$ & $\begin{array}{l}\text { Lipin } \\
\text { ski }\end{array}$ & $\begin{array}{c}\text { Bioavaila } \\
\text { bility } \\
\text { score }\end{array}$ \\
\hline Annonamine & High & -5.80 & Yes & 0.55 \\
\hline Anonaine & High & -5.91 & Yes & 0.55 \\
\hline Xylopine & High & -6.11 & Yes & 0.55 \\
\hline
\end{tabular}

\section{DISCUSSION}

The molecular docking used to analyze interactions between ligands and receptors. From the results of molecular docking, it can be seen the position of ligand binding at the receptor the energy of binding as binding affinity value. The docking process is carried out with Autodock vina software in the PyRx program (Trott and Arthur, 2010). The result of this process is a grid score, which the energy is used by the ligand to bind to a protein, commonly known as Gibbs energy/ bond energy $(\Delta \mathrm{G})$. This docking bond energy is the main parameter to determine the stability of the ligand and protein (Arwansyah et al., 2014).

Analysis of the docking method is scoring, which is calculating the strength of the ligand and receptor bonds expressed by the bond energy $(\Delta G)$. The more negative the $\Delta G$ value, the better the stability level between the ligand and the receptor, so the bonds formed will be stronger (Syahputra et al., 2014).

The results of molecular docking showed the interactions between ligands and proteins. The ligand has a binding site with the specific amino acids at the receptor (Adelin et al., 2013). This binding site affects the conformation and function of the receptor protein. The interaction between ligands and receptors will form hydrogen bonds and hydrophobic bonds (Arwansyah et al., 2014).

The alkyl bonds that are formed on ligand and receptor interactions are a type of hydrophobic bond (Lukman Chaubah et al., 2019). Hydrophobic bonds are a quite important type of bonding in the drugs design other than hydrogen bonds. The hydrophobic bond is one of the keys to the stability of 
ligand and receptor interactions. The presence of water molecules in the hydrophobic bond region makes this area of interaction quite flexible and allows for increased binding affinity (Patil et al., 2010).

\section{CONCLUSION}

From the results of the study it can be concluded that anonamine is the most promising candidate as a phytoestrogen agent because it has a binding ability with a value similar to estradiol as a control. The results of this study provide basic information that can be considered before carrying out the in vivo test in the laboratory.

\section{REFERENCES}

Abdul Wahab, S. M., Jantan, I., Haque, Md. A., \& Arshad, L. (2018). Exploring the Leaves of Annona muricata L. as a Source of Potential Anti-inflammatory and Anticancer Agents. Frontiers in Pharmacology, 9, 661. https://doi.org/10.3389/fphar.2018.006 61

Adelin, T., -, F., \& Aliza, D. (2013). PENAMBATAN MOLEKULER KURKUMIN DAN ANALOGNYA PADA ENZIM SIKLOOKSIGENASE-2. Jurnal Medika Veterinaria, 7(1). https://doi.org/10.21157/j.med.vet..v7i1.2 916

Arwansyah, A., Ambarsari, L., \& Sumaryada, T. I. (2014). Simulasi Docking Senyawa Kurkumin dan Analognya Sebagai Inhibitor Reseptor Androgen pada Kanker Prostat. Current Biochemistry, 1(1), 11-19. https://doi.org/10.29244/cb.1.1.11-19

Couse, J. F., Lindzey, J., Grandien, K., Gustafsson, J.-̊̊., \& Korach, K. S. (1997). Tissue Distribution and Quantitative Analysis of Estrogen Receptor- $\alpha$ (ER $\alpha)$ and Estrogen Receptor- $\beta \quad$ (ER $\beta$ ) Messenger Ribonucleic Acid in the Wild-Type and
ERa-Knockout Mouse. Endocrinology, 138(11), 4613-4621. https://doi.org/10.1210/endo.138.11.5496 Djiogue, S., Halabalaki, M., Njamen, D., Kretzschmar, G., Lambrinidis, G., Hoepping, J., Raffaelli, F., Mikros, E., Skaltsounis, A.-L., \& Vollmer, G. (2014). Erythroidine Alkaloids: A Novel Class of Phytoestrogens. Planta Medica, 80(11), 861-869. https://doi.org/10.1055/s0034-1382861

Fait, T. (2019). Menopause hormone therapy: Latest developments and clinical practice. Drugs in Context, 8, 1-9. https://doi.org/10.7573/dic.212551

Hamilton, K. J., Arao, Y., \& Korach, K. S. (2014). Estrogen hormone physiology: Reproductive findings from estrogen receptor mutant mice. Reproductive Biology, 14(1), 3-8. https://doi.org/10.1016/j.repbio.2013.12. 002

Hemalatha, V. T., Julius, A., Kumar, S. P. K., Vijayalakshmi, L., \& Narayanan, S. (2019). Estrogen deficiency during menopause and its management: $A$ current update. Drug Invention Today, 12(2), 7.

Lukman Chaubah, M. A., Wihelmina Bontes, B., \& Afifah Mulachelah, N. (2019). Molecular Docking of Polycyclic Aromatic Hydrocarbons as Potentially Carcinogenic Molecules Through Binding with Aryl Hydrocarbon Receptor. JSMARTech, 1(1), 12-15. https://doi.org/10.21776/ub.jsmartech.2 019.001.01.3

Nikolić, I., Savić-Gajić, I., Tačić, A., \& Savić, I. (2017). Classification and biological activity of phytoestrogens: A review. Advanced Technologies, 6(2), 96-106. https://doi.org/10.5937/savteh1702096 $\mathrm{N}$

Nilsson, S., Mäkelä, S., Treuter, E., Tujague, M., Thomsen, J., Andersson, G., Enmark, E., Pettersson, K., Warner, M., \& Gustafsson, J.-Å. (2001). Mechanisms of Estrogen Action. Physiological Reviews, 
81(4), 1535-1565. https://doi.org/10.1152/physrev.2001.81. 4.1535

Patil, R., Das, S., Stanley, A., Yadav, L., Sudhakar, A., \& Varma, A. K. (2010). Optimized Hydrophobic Interactions and Hydrogen Bonding at the TargetLigand Interface Leads the Pathways of Drug-Designing. PLoS ONE, 5(8), e12029.

https://doi.org/10.1371/journal.pone.001 2029

Syahputra, G., Ambarsari, L., \& Sumaryada, T. (2014). SIMULASI DOCKING KURKUMIN ENOL, BISDEMETOKSIKURKUMIN DAN ANALOGNYA SEBAGAI INHIBITOR ENZIM12-LIPOKSIGENASE. 13.

Trott, Olet and Arthur J. Olson. (2010). AutoDock Vina: improving the speed and accuracy of docking with a new scoring function, efficient optimization and multithreading. $J$ Comput Chem 30; 31(2): 455-461. doi:10.1002/jcc.21334.

Yue, W., Wang, J.-P., Li, Y., Fan, P., Liu, G., Zhang, N., Conaway, M., Wang, H., Korach, K. S., Bocchinfuso, W., \& Santen, R. (2010). Effects of estrogen on breast cancer development: Role of estrogen receptor independent mechanisms. International Journal of Cancer, $\quad 127(8), \quad 1748-1757$. https://doi.org/10.1002/ijc.25207

Zhu, J., Wang, J., Yu, H., Li, Y., \& Hou, T. (2011). Recent Developments of In Silico Predictions of Oral Bioavailability. Combinatorial Chemistry \& High Throughput Screening, 14(5), 362-374. https://doi.org/10.2174/13862071179550 8368 